\title{
МЕТОДИЧНІ ЗАСАДИ ФОРМУВАННЯ КОНКУРЕНТОСПРОМОЖНОСТІ АВІАПІДПРИЕМСТВА НА ОСНОВІ ЙОГО БІЗНЕС-МОДЕЛІ
}

\author{
3. М. ПОБЕРЕЖНА \\ кандидат економічних наук, доцент, \\ Національний авіаційний університет
}

\begin{abstract}
Анотація. Мета статті полягає у формуванні конкурентоспроможності авіапідприємства на основі бізнес-моделі. Структуризація бізнес-моделі як відкритої системи дала можливість виділити основні ї̈ елементи, серед яких головними є керуюча та керована системи. Методика дослідження. Досягнення поставленої у статті мети здійснено за допомогою таких методів дослідження, як методи логічного узагальнення та наукової абстракиії, структурного аналізу, аналітичного методу. Результати. Обгрунтовано взаємозв 'язок бізнес-моделі, бізнес-процесів та ланцююга створення вартості підприємства з конкурентними перевагами в єдиному системному контурі. Розкрито сутність кожного елементу та аргументовано його роль $і$ значення у забезпеченні конкурентоспроможності авіапідприємства. Доведено, щзо потреби споживачів визначають бажану иінність послуги авіаційного підприємства, яку покладено в основу ланцүюга створення цінності, чим визначено витрати підприємства, щзо забезпечують продукування базової цүінності та диференціацуію цієї цуінності залежно від зміни ї̈ вартості. Залежно від ролі бізнес-процесів, яку вони відіграють у бізнес-моделі підприємства, відбувається формування доданої вартості. Бізнес-процееси виступають цеентрами формування витрат чи прибутку. Встановлено, щчо цінність для споживача формують структура маршрутної мережі; частота рейсів, тарифи; класи обслуговування; стандарти якості; якість обслуговування, а також інші види діяльності, які дають можливість отримати прибуток, інші ж витрати не визначають для споживача ніякої цінності, а просто забезпечують діяльність авіапідприємств, тому потребують постійної оптимізаиії. Представлено авторський ланиюг створення цінності авіапідприємства, який передбачає поділ послуги на такі види, як передпольотне обслуговування, польотне обслуговування, міжпольотне обслуговування та післяпольотне обслуговування. Узагальнено перелік складових елементів, комбінація яких буде видозмінюватися залежно від бізнес-моделі підприємства та компонентів, які наповнюють ланцюг створення ицінності і безпосередньо формують собівартість послуги авіапідприсмства. Практична значущість результатів дослідження. Використання на практиці запропонованих теоретичних та практичних рекомендацій дасть змогу авіапідприємству забезпечити стійку конкурентну позицію на вітчизняному та міжнародному ринках.
\end{abstract}

Ключові слова: бізнес-модель, конкурентоспроможність, авіапідприємства, бізнес-прочеси, ланцюг створення циінності, базова ијінність, додаткова ијінність.

Постановка проблеми в загальному вигляді та ії зв'язок із найважливішими науковими чи практичними завданнями. Формування конкурентоспроможності авіапідприємства є складним процесом, який відбувається в умовах ризикованого та невизначеного зовнішнього середовища, прямо залежить від мінливих вимог споживачів та наявних або потенційних ресурсів авіапідприємства. Вирішення завдання формування конкурентоспроможності авіапідприємств на основі бізнесмоделі нині реалізується на засадах системного підходу, адже жорстка конкуренція на авіаційному ринку актуалізує питання застосування новітніх методів конкурентної боротьби, що базуються на конкурентних перевагах кожної окремої бізнесмоделі авіапідприємства, а точніше, на обгрунтуванні складових елементів ланцюга створення іiі цінності для кінцевого споживача, що безпосередньо відображається на ціні кінцевого продукту.

Аналіз останніх досліджень і публікацій. Теоретичним засадам сутності таких понять, як «цінність», «ланцюг створення цінності», присвя- чені праці таких класиків, як М. Портер, Р. Ален, Дж.Р. Хікс, К. Прахлад, Дж. Стрікленд, В. Гальперін, М. Туган-Барановський, Д. Хлєбніков.

Серед вітчизняних дослідників, чиї праці присвячено питанням ланцюга поставок та ланцюга корисностей, слід виділити таких, як О. Костюк [1], Н. Чухрай, О. Гірна [2; 3]. Низка питань щодо показників цінності підприємства висвітлено в працях О. Мниха [4] та В. Короля [5].

Відзначимо, що питання формування бізнесмоделей та ланцюга створення цінності на авіапідприємствах мають фрагментарний характер. Частково коло питань, присвячених ланцюгу створення цінності авіаційної послуги, окреслено у працях К. Калди [6], Н. Антощишиної, М. Григорака $[7 ; 8]$. Саме тому опрацювання питань 3 вибраної проблематики $є$ надзвичайно актуальним та вимагає подальшого й більш глибинного вивчення та систематизації.

Формування цілей статті (постановка завдання). Метою статті є обгрунтування методичних засад формування конкурентоспромож- 
ності авіапідприємства на основі його бізнесмоделі.

Виклад основного матеріалу дослідження 3 повним обгрунтуванням отриманих наукових результатів. Бізнес-модель підприємства спрямована на раціоналізацію та оптимізацію усіх бізнес-процесів ланцюга створення вартості, а їi головною метою є підвищення прибутковості за рахунок максимального задоволення потреб споживачів.

Саме тому визначення місця та ролі бізнесмоделі підприємства в системі забезпечення його конкурентоспроможності має велике значення для функціонування підприємства. На рис. 1 представлено внутрішню структуру системи формування конкурентоспроможності підприємства на основі бізнес-моделі. Розглянемо внутрішню структуру системи формування конкурентоспроможності 3 позицій функцій та об’єктів.

3 огляду на те, що конкурентоспроможність авіапідприємства визначається перш за все конкурентоспроможністю його послуг, побудова керуючої системи базується на основі життєвого циклу послуги.

Функціональні блоки керованої системи передбачають поєднання всього комплексу, що стосується надання послуг авіаційними підприємствами, складниками якого є персонал підприємства; фінансове забезпечення; матеріальнотехнічне забезпечення; процес виконання робіт i надання послуг; система забезпечення якості, системи маркетингу та збуту, логістична система. Така підсистема поєднує об'єкт управління та суб'єкт управління на авіапідприємстві, які обов'язково визначаються моделлю ведення бізнесу підприємства або декількома такими моделями. Функціональні блоки системи відображають відповідні напрями реалізації бізнес-моделі авіапідприємства.

Бізнес-модель поєднує низку бізнес-процесів, а саме основних, забезпечувальних, бізнес-процесів управління, розвитку. Бізнес-моделлю та бізнес-процесами кожного окремого авіапідприємства визначено ланцюг створення вартості для споживача, який є унікальним для кожної бізнесмоделі, поєднує різну кількість складових частин кожного елементу ланцюга, який передбачає перш за все передпольотне обслуговування; польотне обслуговування; міжпольотне обслуговування; післяпольотне обслуговування.

Розглянемо елементи керуючої системи. Функціональна підсистема реалізує загальні та конкретні функції керуючої системи суб'єкта управління формуванням конкурентоспроможності авіапідприємства. До загальних функцій варто віднести планування та прогнозування конкурентоспроможності підприємства, яка імплементована у загальну стратегію підприємства на всіх iii рівнях, організацію процесу формування конкурентоспроможності, облік, контроль та аналіз. Зв'язок керуючої та керованої систем реалізується через виділені окремі функціональні зони, такі як виробництво, маркетинг, фінанси, персонал.

Цільова підсистема системи формування конкурентоспроможності авіаційного підприємства на основі бізнес-моделі є відкритою цілеспрямованою системою, загальною метою якої $є$ формування конкурентоспроможності підприємства. Її реалізація вбачається у створенні та реалізації конкурентних переваг. Під час формування цільової підсистеми слід враховувати їі взаємозв'язок iз зовнішнім середовищем, оскільки зовнішнє середовище може також виступати джерелом отримання конкурентних переваг підприємства.

Організаційно-структурна підсистема відображає поєднання виробничої структури авіапідприємства та структури управління, що визначаються бізнес-моделлю, яку реалізує підприємство в процесі своєї діяльності та яка обумовлена їі бізнеспроцесами й ланцюгом створення цінності для споживача, що спрямовані на формування конкурентоспроможності авіапідприємства.

Інформаційно-технологічна підсистема поєднує всі інформаційні потоки підприємства (внутрішні та зовнішні), що беруть участь в інформаційному забезпеченні процесу прийняття управлінських рішень. Ця підсистема характеризується сукупністю економіко-математичних моделей, програмним та технічним забезпеченням усього виробничо-управлінського процесу в ході формування конкурентоспроможності авіапідприємства на основі бізнес-моделі, а також базується на використанні сучасних інформаційних технологій та засобів комунікації.

Бізнес-модель характеризує модель ведення справ, яку компанія використовує для створення цінності й отримання прибутку 3 урахуванням сформованих конкурентних переваг. Підприємство може використовувати одразу декілька бізнес-моделей для отримання прибутку.

На рис. 2 узагальнено перелік складових елементів, комбінація яких буде видозмінюватися залежно від бізнес-моделі підприємства та компонентів, які наповнюють ланцюг створення цінності для кінцевого споживача.

Реалізація бізнес-моделі передбачає поєднання низки бізнес-процесів, у ході яких створюється конкурентна перевага та формується конкурентоспроможність підприємства на ринку. До основних бізнес-процесів належать процеси, які повністю відображають бізнес-напрями діяльності авіапідприємства (профіль бізнесу); виступають джерелом отримання прибутку; мають визначальне (стратегічне значення) тощо.

Забезпечувальні бізнес-процеси допомагають оптимальному протіканню основних бізнес-проце- 


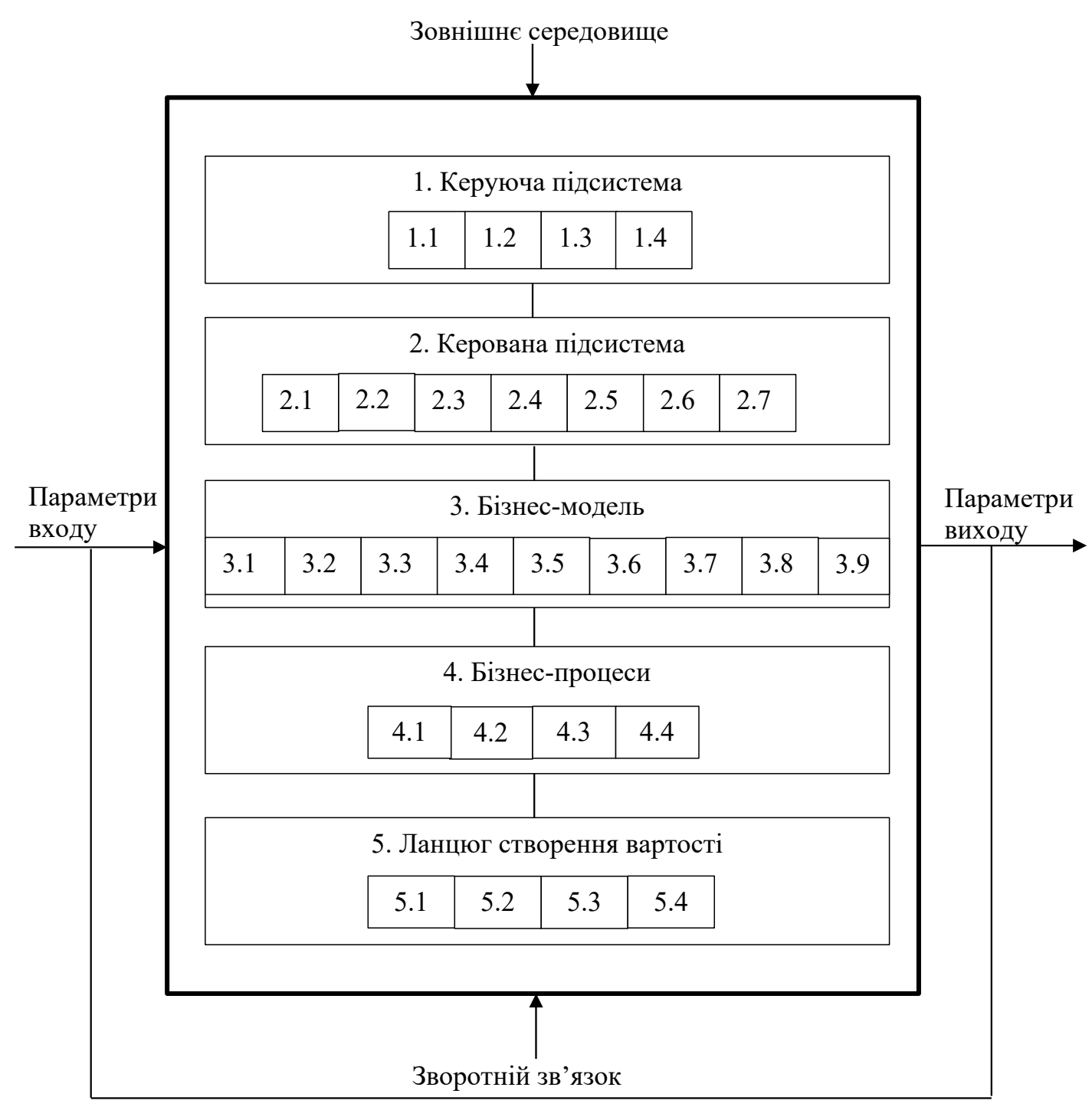

Рис. 1. Структура системи формування конкурентоспроможності авіапідприємства на основі бізнес-моделі Джерело: авторська розробка

1. Керуюча підсистема:

1.1. Функціональна підсистема управління

1.2. Цільова підсистема

1.3. Організаційно-структурна підсистема

1.4. Інформаційно-технологічна підсистема

2. Керована підсистема:

2.1. Персонал підприємства

2.2. Фінансове забезпечення

2.3. Матеріально-технічне забезпечення

2.4. Процес виробництва товарів, виконання робіт та надання послуг

2.5. Система забезпечення якості
2.6. Система маркетингу та збуту

2.7. Логістична система

3. Бізнес-моделі:

3.1. Регулярні міжнародні авіакомпанії

3.2. Регіональні авіакомпанії

3.3. Мережеві авіакомпанії

3.4. Чартерні авіакомпанії

3.5. Низьковитратні авіакомпанії

3.6. Вантажні авіакомпанії

3.7. Змішані (диференційовані) авіакомпанії

3.8. Ізольовані авіакомпанії

3.9. Бізнес (VIP) авіакомпанії
4. Бізнес-процеси:

4.1. Основні бізнес-процеси

4.2. Бізнес-процеси управління

4.3 Бізнес-процеси розвитку

4.4. Забезпечувальні бізнес-процеси

5. Ланцюг створення вартості:

5.1. Передпольотне обслуговування

5.2. Польотне обслуговування

5.3. Міжпольотне обслуговування

5.4. Післяпольотне обслуговування сів, створюючи інфраструктуру для їх виконання. Їх головними споживачами вступають перш за все підрозділи підприємства, працівники та основні бізнес-процеси. Вони не мають для авіапідприємства стратегічного значення, можуть продаватися на зовнішньому ринку або за недоцільності їх виконання мажуть бути передані в аутсорсинг.

Бізнес-процеси управління - це група процесів, перебіг яких не передбачає формування цін- ності, але вони спрямовані на забезпечення ефективної реалізації основних бізнес-процесів.

Метою бізнес-процесів розвитку $є$ забезпечення розвитку підприємства у довгостроковому періоді та формування додаткової вартості на базі наявних і перспективних конкурентних переваг задля максимального задоволення наявного та перспективного попиту споживачів. Такі процеси можуть існувати як у разових діях підприємства 


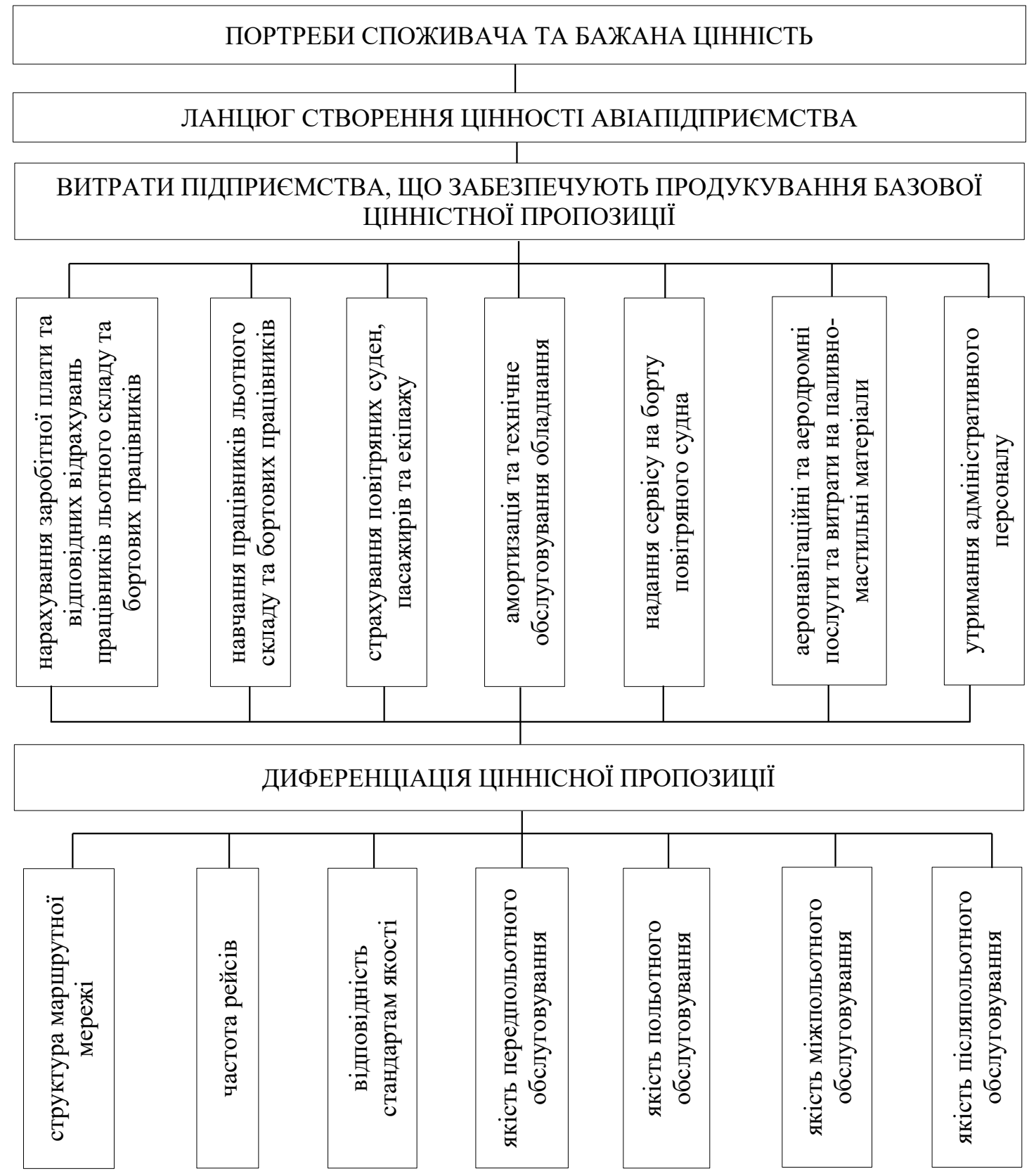

Рис. 2. Складові елементи системи формування конкурентоспроможності авіапідприємства на основі бізнес-моделі

Джерело: авторська розробка

щодо реструктуризації, модернізації підприємства, реінжинірингу, створення та виведення на ринок нових товарів та послуг, що спрямовані та стратегічний розвиток підприємства, так і у формах довгострокових інвестицій або венчурного капіталу [9].

Такий підхіддо поділу бізнес-процесів, на нашу думку, є зрозумілим та зручним у використанні, а також дає можливість менеджерам ефективно керувати та спостерігати за процесами діяльності підприємства, своєчасно впроваджуючи необхідні зміни. 3 огляду на те, яку роль відіграють бізнеспроцеси і яким чином вони беруть участь у про- цесі формування доданої вартості (тобто виступають центрами формування витрат чи прибутку), менеджери можуть приймати рішення щодо розвитку або ліквідації непродуктивних бізнеспроцесів.

До центрів формування витрат належать бізнеспроцеси, які передбачають утримання адміністративного персоналу; нарахування заробітної плати та відповідних відрахувань працівників льотного складу та бортових працівників, навчання працівників льотного складу та бортових працівників; страхування повітряних суден, пасажирів та екіпажу; амортизація та технічне обслуговування 
обладнання; надання сервісу на борту повітряного судна, представлення харчування на борту; аеронавігаційні та аеродромні послуги й витрати на паливно-мастильні матеріали.

Центрами формування прибутку, тобто формування цінності для кінцевого споживача, є структура маршрутної мережі; частота рейсів, тарифи; класи обслуговування; стандарти якості; якість обслуговування, а також інші види діяльності, які дають можливість отримати прибуток [7].

Ланцюг створення вартості є важливим елементом управління бізнес-моделлю та джерелом отримання конкурентних переваг у процесі формування конкурентоспроможності авіапідприємства. Цей ланцюг поєднує чотири основні блоки, такі як передпольотне обслуговування; польотне обслуговування; міжпольотне обслуговування; післяпольотне обслуговування.

Загалом ланцюг створення вартості роботи чи послуги є результатом додавання прибутку до собівартості усіх видів діяльності авіапідприємства, причому на авіаційному підприємстві, як і на будь-якому іншому, формуються як постійні, так і змінні витрати.

Задля визначення додаткових можливостей отримання прибутку на прикладі авіакомпаній H.I. Антощишиною запропоновано «ланцюг цінності авіатранспортної послуги поділити на дві складові частини, а саме базову цінність послуги i додаткову цінність послуги, який забезпечує отримання додаткового доходу авіаційної компанії». Проаналізовано ланцюг створення цінності різних авіаційних підприємств, виявлено, що традиційні авіакомпанії мають майже однаковий ланцюг, у якого частина базової цінності є уніфікованою, а відрізняється тільки друга частина, тобто його наповнення, саме створення цінності додаткової послуги. Ланцюг цінності традиційної бізнес-моделі авіаційної компанії за іiї наповненням та структурою складових частин як базової, так і додаткової цінності відрізняється від ланцюга цінності малобюджетної моделі ведення бізнесу [7].

На відміну від традиційної бізнес-моделі, малобюджетні авіапідприємства не мають уніфікованого переліку компонентів наповнення ланцюга створення цінності для споживча, тобто кожна окрема малобюджетна компанія вирішує самостійно склад і перелік елементів базової та додаткової цінності власної компанії. Це перш за все пояснюється тим, що кожна малобюджетна компанія задля зменшення витрат і збільшення прибутку може частину змінних витрат віднести до категорії «доходи від неавіаційної діяльності», а постійні витрати переглянути, отже, частково низку тих бізнес-процесів, що їх формують, виконувати самостійно задля економії. Також зменшення витрат малобюджетними авіапідпри- ємствами можна забезпечити через передачу тих бізнес-процесів, які не створюють безпосередньо цінність для споживача в аутсорсинг (бухгалтерія, маркетинг, наземне обслуговування повітряних суден тощо).

3 огляду на проведене дослідження на рис. 3 представлено авторський ланцюг створення цінності авіапідприємства.

Таким чином, кожне авіапідприємство залежно від мети діяльності та позиціювання себе на ринковій арені самостійно приймає низку рішень, пов'язаних із кількістю складових елементів ланцюга створення цінності для споживачів, та формує власний шлях зменшення витрат, адже саме врегулювання цінності для споживача та ціни послуги може створити для підприємства унікальну конкурентну перевагу у забезпеченні його конкурентоспроможності на ринку та забезпечити лідируючу позицію серед інших авіапідприємств у галузі.

Визначення моделі ведення бізнесу обумовлює вибір бізнес-процесів ії реалізації та структуру складових елементів ланцюга створення цінності для споживача в межах цієї бізнес-моделі. Взаємозв'язок елементів структури формування конкурентоспроможності авіапідприємства на основі бізнес-моделі пояснюється тим, що в процесі створення цінності для споживачів авіапідприємство може приймати будь-які рішення щодо впровадження нових методів організації бізнесу, які ведуть до усіх змін керуючої та керованої систем. Отже, в системі формування конкурентоспроможності на основі бізнес-моделі керуючий вплив 3 боку суб'єктів управління спрямований на об'єкти управління, які представлені бізнесмоделлю, бізнес-процесами та ланцюгом створення цінності авіапідприємства.

З огляду на проведене дослідження відзначимо, що формування конкурентоспроможності авіапідприємства на основі побудови бізнес-моделі за сучасних умов господарювання впливає на зростання продуктивності суспільної праці, темпи та ефективність науково-технічного прогресу, структуру виробництва та функціональний розподіл потужностей, забезпечує ефективне використання основних фондів, економію сировини, матеріалів, палива, енергії, зростання ефективності інвестицій. Бізнес-модель авіапідприємства описує те, яким чином воно позиціонує себе в ланцюжку створення цінності в рамках своєї галузі, а також як воно створює прибуток.

Представлено авторську внутрішню структуру системи формування конкурентоспроможності підприємства на основі бізнес-моделі, яка включає низку елементів, таких як керуюча та керована підсистеми, бізнес-моделі, бізнес-процеси та ланцюг створення цінності, які у тісній взаємодії дадуть можливість авіапідприємству забезпечити 


\begin{tabular}{|c|c|c|c|}
\hline \multicolumn{4}{|c|}{ ЛАНЦЮГ СТВОРЕННЯ ЦІННОСТІ АВІАПІДПРИЄМСТВА } \\
\hline $\begin{array}{l}\text { передпольотне } \\
\text { обслуговування }\end{array}$ & $\begin{array}{c}\text { польотне } \\
\text { обслуговування }\end{array}$ & $\begin{array}{c}\text { міжпольотне } \\
\text { обслуговування }\end{array}$ & $\begin{array}{l}\text { післяпольотне } \\
\text { обслуговування }\end{array}$ \\
\hline \multicolumn{4}{|c|}{ ЕЛЕМЕНТИ ЦІННОСТІ } \\
\hline \multicolumn{4}{|c|}{ БАЗОВА ЦІННІСТЬ } \\
\hline $\begin{array}{l}\text { - інформування споживачі } \\
\text { про авіапідприємство; } \\
\text { - продаж авіаквитків; } \\
\text { - сервісне інформаційне } \\
\text { обслуговування в } \\
\text { аеропорту; } \\
\text { - реєстрація, посадка на } \\
\text { борт літака, дотримання } \\
\text { графіку польотів; } \\
\text { - безпека в аеропорту }\end{array}$ & $\begin{array}{l}\text { - забезпечення } \\
\text { безпеки польоту; } \\
\text { - надання } \\
\text { інформації про } \\
\text { політ }\end{array}$ & $\begin{array}{l}\text { дотримання } \\
\text { графіку польотів } \\
\text { для пересадки на } \\
\text { стиковочні рейси }\end{array}$ & $\begin{array}{l}\text { - висадка з літака; } \\
\text { - проходження } \\
\text { контролю; } \\
\text { - отримання багажу }\end{array}$ \\
\hline \multicolumn{4}{|c|}{ ДОДАТКОВА ЦІННІСТЬ } \\
\hline $\begin{array}{l}\text { - допомога у бронюванні } \\
\text { квитків; } \\
\text { - доставка до аеропорту; } \\
\text { - сервісне обслуговування } \\
\text { в аеропорту; } \\
\text { - дотримання графіків } \\
\text { польотів; } \\
\text { - доставка до літака; } \\
\text { - оформлення багажу; } \\
\text { - встановлення ліміту } \\
\text { багажу }\end{array}$ & $\begin{array}{l}\text { - забезпечення } \\
\text { безпеки польоту; } \\
\text { - можливість } \\
\text { вибрати місце } \\
\text { в салоні; } \\
\text { - бортове } \\
\text { харчування; } \\
\text { - доступ до } \\
\text { Інтернету; } \\
\text { - додатковий сервіс }\end{array}$ & $\begin{array}{l}\text { - допомога під час } \\
\text { пересадки на } \\
\text { інший літак; } \\
\text { - замовлення таксі; } \\
\text { - замовлення } \\
\text { готелю; } \\
\text { - автоматичне } \\
\text { перевантаження } \\
\text { багажу на інший } \\
\text { літак }\end{array}$ & $\begin{array}{l}\text { - доставка від } \\
\text { повітряного судна } \\
\text { до аеропорту; } \\
\text { - трансфер від } \\
\text { аеропорту до точки } \\
\text { призначення; } \\
\text { - забезпечення } \\
\text { неушкодженості } \\
\text { вантажу; } \\
\text { - розшук загубленого } \\
\text { вантажу }\end{array}$ \\
\hline \multicolumn{4}{|c|}{$\begin{array}{c}\text { РИНКОВІ АГЕНТИ, ЩО ЗАБЕЗПЕЧУЮТЬ ОПТРИМАЛЬНЕ ПРОТІКАННЯ БІЗНЕС- } \\
\text { ПРОЦЕСІВ ФОРМУВАННЯ ЦІННОСТІ АВІАПІДПРИЄМСТВА }\end{array}$} \\
\hline $\begin{array}{l}\text { - рекламні агентства; } \\
\text { - туристичні агентства; } \\
\text { - каси продажу квитків; } \\
\text { - представники } \\
\text { авіапідприємства; } \\
\text { - дистриб'ютори; } \\
\text { - інформаційні } \\
\text { агентства; } \\
\text { - служба охорони } \\
\text { аеропорту; } \\
\text { - служби сервісного } \\
\text { обслуговування }\end{array}$ & $\begin{array}{l}\text { - диспетчерські } \\
\text { служби та служби } \\
\text { безпеки польоту; } \\
\text { - клінінгові компанії; } \\
\text { - заклади, що } \\
\text { передають } \\
\text { харчування на борт } \\
\text { повітряних суден; } \\
\text { - інтернет- } \\
\text { провайдери; } \\
\text { - друковані видання, } \\
\text { що надають } \\
\text { літературу на борт } \\
\text { повітряних суден }\end{array}$ & $\begin{array}{l}\text { - служби } \\
\text { аеропортів та } \\
\text { елементи їх } \\
\text { інфраструктури; } \\
\text { - інтернет- } \\
\text { провайдери }\end{array}$ & $\begin{array}{l}\text { - митна та охоронна } \\
\text { служби аеропортів; } \\
\text { - аеропортова служба } \\
\text { доставки вантажудо } \\
\text { місця його видачі; } \\
\text { - служби видачі та } \\
\text { розшуку вантажу; } \\
\text { - служба доставки } \\
\text { споживачів від } \\
\text { повітряного судна } \\
\text { до аеропорту; } \\
\text { - служба трансферту; } \\
\text { - служба оренди } \\
\text { автомобілів }\end{array}$ \\
\hline
\end{tabular}

Рис. 3. Складові частини ланцюга створення цінності авіапідприємства

Джерело: авторська розробка

стійку конкурентну позицію на вітчизняному та міжнародному ринках. Виділені блоки цієї системи поєднують достатню кількість елементів, які забезпечують функціонування щодо формування iї конкурентоспроможності.
Висновки із зазначених проблем i перспективи подальших досліджень у поданому напрямі. Встановлено, що конкурентоспроможність авіапідприємства на основі бізнес-моделі буде залежати від кінцевого споживача, потреби та 
вимоги якого до тієї чи іншої ціннісної пропозиції висуваються на перший план, а також ціни, яку він готовий за неї платити, тому формування конкурентоспроможності авіаційного підприємства на основі бізнес-моделі буде містити і витрати, і дифе- ренціацію продукту, які у своїй сукупності складуть ланцюг створення цінності та $є$ важливими для формування цінності для споживача, а за сприятливих умов стануть конкурентною перевагою на ринку.

\section{СПИСОК ВИКОРИСТАНИХ ДЖЕРЕЛ}

1. Костюк О. Концепція інтегрованого ланцюга поставок в лісопромисловому комплексі. Регіональна економіка. 2005. № 2. С. 271-278.

2. Чухрай Н., Гірна О. Формування ланцюгів поставок: питання теорії та практики. Львів : Інтелект-Захід, 2007. 232 c.

3. Гірна О., Кобилюх О., Хтей Н. Формування корисностей у ланцюгу поставок на основі ринкової пропозиції. Вісник Національного університету «Львівська політехніка». Логістика. 2006. № 552. С. 17-23.

4. Мних О. Трансформація власності у розвитку відносин «підприємство - клієнт» : монографія. Львів : Видавництво Національного університету «Львівська політехніка», 2007. 250 с.

5. Король В. Про цінність і вартість в системі фінансового менеджменту. URL: http://ua-stock.com/assets/files/ value.pdf (дата звернення: 22.07.2021).

6. Калда К. Логістичний підхід до формування ланцюгів створення цінності та вартості авіатранспортної продукції. Вісник Хмельницького національного університету. Економічні науки. 2009. № 1. С. $206-211$.

7. Антощишина H. Теоретичні положення формування інтегрованої цінності авіакомпанії. URL: http://jrnl.nau.edu.ua/index.php/PPEI/article/view/152 (дата звернення: 22.07.2021).

8. Антощишина Н., Григорак M. Математична модель формування інтегрованої цінності авіакомпанії. URL: http://jrnl.nau.edu.ua/index.php/PPEI/article/view/233 (дата звернення: 22.07.2021).

9. Ткачук Г., Кушніренко О. Формування бізнес-моделі підприємства. Житомир : ЖДТУ, 2016.222 с.

\section{REFERENCES}

1.Kostyuk O. (2005) Kontseptsiya intehrovanoho lantsyuha postavok v lisopromyslovomu kompleksi [The concept of an integrated supply chain in the timber industry]. Rehionalna ekonomika, no. 2, pp. 271-278. (in Ukrainian)

2. Chukhray N., Hirna O. (2007) Formuvannya lantsyuhiv postavok: pytannya teoriyi ta praktyky [Formation of supply chains: questions of theory and practice]. Lviv, Intelekt-Zakhid, 232 p. (in Ukrainian)

3. Hirna O., Kobylyukh O., Khtey N. (2006) Formuvannya korysnostey u lantsyuhu postavok na osnovi rynkovoyi propozytsiyi [Formation of utilities in the supply chain based on market supply]. Visnyk Natsionalnoho universytetu "Lvivska politekhnika". Lohistyka, no. 552, pp. 17-23. (in Ukrainian)

4. Mnykh O. (2007) Transformatsiya vlasnosti u rozvytku vidnosyn "pidpryyemstvo - kliyent" [Transformation of property in the development of "enterprise - client" relations]. Monograph. Lviv: Vydavnytstvo Natsionalnoho universytetu "Lvivska politekhnika", 250 p. (in Ukrainian)

5. Korol V. Pro tsinnist i vartist v systemi finansovoho menedzhmentu [About value and cost in the system of financial management]. Available at: http://ua-stock.com/assets/files/value.pdf (accessed 22 July 2021). (in Ukrainian)

6. Kalda K. (2009) Lohistychnyy pidkhid do formuvannya lantsyuhiv stvorennya tsinnosti ta vartosti aviatransportnoyi produktsiyi [Logistic approach to the formation of value chains and the value of air transport products]. Visnyk Khmelnytskoho Natsionalnoho Universytetu. Ekonomichni nauky, no. 1, pp. 206-211. (in Ukrainian)

7. Antoshchyshyna N. Teoretychni polozhennya formuvannya intehrovanoyi tsinnosti aviakompaniyi [Theoretical provisions for the formation of the integrated value of the airline]. Available at: http://jrnl.nau.edu.ua/index.php/PPEI/ article/view/152 (accessed 22 July 2021). (in Ukrainian)

8. Antoshchyshyna N., Hryhorak M. Matematychna model formuvannya intehrovanoyi tsinnosti aviakompaniyi [Mathematical model of airline integrated value formation]. Available at: http://jrnl.nau.edu.ua/index.php/PPEI/article/ view/233 (accessed 22 July 2021). (in Ukrainian)

9. Tkachuk H., Kushnirenko O. (2016) Formuvannya biznes-modeli pidpryyemstva [Formation of business model of the enterprise]. Zhytomyr: ZHDTU, 222 p. (in Ukrainian)

3. Н. Побережная, Нацииональный авиациионый университет. Методические основы формирования конкурентоспособности авиапредприятия на основе его бизнес-модели.

Аннотация. Цель статьи заключается в формировании конкурентоспособности авиапредприятия на основе бизнес-модели. Структуризация бизнес-модели как открытой системы позволила выделить основные ее элементы, среди которых главными являются управляющая и управляемая системы. Методика исследования. Достижение поставленной в статье изели осуществлено с помощью таких методов исследования, как методы логического обобщения и научной абстракции, структурного анализа, аналитического метода. Результаты. Обоснована взаимосвязь бизнес-модели, бизнес-прочессов и цеепочки создания стоимости предприятия с конкурентными преимуществами в едином системном контуре. Раскрыта сущиность каждого элемента и аргументированы его роль и значение в обеспечении конкурентоспособности авиапредприятия. Доказано, что потребности потребителей определяют желаемую иченность услуги авиационного предприятия, которая положена в основу иепочки создания цченности, чем определень 
расходы предприятия, обеспечивающче выработку базовой цүенности и дифференциацию этой цุенности в зависимости от изменения ее стоимости. В зависимости от роли бизнес-процессов, которую они играют в бизнес-модели предприятия, происходит формирование добавленной стоимости. Бизнес-проиессь выступают изентрами формирования затрат или прибыли. Установлено, что изенность для потребителя формируют структура маршрутной сети; частота рейсов, тарифы; классы обслужсвания; стандартыл качества; качество обслуживания, а также другие виды деятельности, которые дают возможность получить прибыль, другие же расходы не определяют для потребителя никакой ценности, а просто обеспечивают деятельность авиапредприятий, поэтому нуждаются в постоянной оптимизации. Представлена авторская ичепь создания иенности авиапредприятия, которая предусматривает разделение услуги на такие виды, как передполетное обслуживание, полетное обслуживание, межполетное обслуживание и послеполетное обслуживание. Обобщен перечень составляюших элементов, комбинация которых будет видоизменяться в зависимости от бизнес-модели предприятия и компонентов, которые наполняют иепь создания ценности и непосредственно формируют себестоимость услуги авиапредприятия. Практическая значимость результатов исследования. Использование на практике предложенных теоретических и практических рекомендаций позволит авиапредприятию обеспечить устойчивую конкурентную позицию на отечественном и международном рынках.

Ключевые слова: бизнес-модель, конкурентоспособность, авиапредприятия, бизнес-процессы, изепь создания иченности, базовая цченность, дополнительная цченность.

Zarina Poberezhna, National Aviation University. Methodological principles of formation of the competitiveness of the aviation enterprise on the basis of its business model.

Annotation. The purpose of the article is to form the competitiveness of the aviation enterprise based on the business model. The structuring of the business model as an open system made it possible to identify its main elements, among which the main ones are: control and managed system. Methodology of research. Achieving the goal set in the article is carried out using the following research methods: logical generalization and scientific abstraction, structural analysis, analytical method. Findings. The interrelation of the business model, business processes and the value chain of the enterprise with the competitive advantages in a single system circuit is substantiated. The essence of each element is revealed and its role and significance in ensuring the competitiveness of the aviation enterprise is argued. It is proved that the needs of consumers determine the desired value of the service of the aviation enterprise, which is the basis of the value chain, which determines the costs of the enterprise, providing the production of base value and differentiation of this value depending on changes in its value. Depending on the role of business processes that they play in the business model of the enterprise, value added is formed. Business processes are the centers of cost or profit. It is established that the value for the consumer is formed by the structure of the route network; frequency of flights, fares; service classes; quality standards; quality of service, as well as other activities that provide an opportunity to make a profit, while other costs do not determine any value for the consumer, but simply provide the activities of aviation enterprises, so they need constant optimization. The author's chain of value creation of the aviation enterprise is presented, which provides for the division of services into such types as: before flight service, flight service, between flight service and after flight service. The list of constituent elements is generalized, the combination of which will vary depending on the business model of the enterprise and the components that fill the value chain and directly form the cost of the aviation enterprise's service. Practical value. The practical use of the proposed theoretical and practical recommendations will allow the aviation enterprise to ensure a stable competitive position in domestic and international markets.

Keywords: business model, competitiveness, aviation enterprise, business processes, value chain, basic value, added value. 